\title{
A Contextual Review on the Evolution of Corporate Social Responsibility
}

\author{
Tan Seng Teck ${ }^{1}$, Selvamalar Ayadurai ${ }^{2} \&$ William Chua ${ }^{3}$ \\ ${ }^{1}$ Senior Lecturer, Faculty of Business, Communication and Law (FOBCAL), INTI International University, \\ Malaysia \\ ${ }^{2}$ Principal Consultant, Talenpac, PLT, Malaysia \\ ${ }^{3}$ Associate Professor, IPE School of Management, Paris, France \\ Correspondence: Tan Seng Teck, Faculty of Business Communication and Law (FOBCAL), INTI International \\ University, Malaysia. E-mail: sengteck.tan@newinti.edu.my
}

Received: September 10, 2019

Accepted: October 9, 2019 Online Published: November 23, 2019

doi:10.5539/jms.v9n2p136

URL: https://doi.org/10.5539/jms.v9n2p136

\begin{abstract}
This article attempts the perilous tasks of reviewing corporate social responsibility. Reviewing those literatures is a notorious challenge because corporate social responsibility has developed inconsistently. Authors that insist a precise definition are often disappointed because corporate social responsibility is a relative concept. It has never assumed a stagnated role. To encaptivate this review, this article peruses corporate social responsibility from a contextual approach. It reviews the development of corporate social responsibility at every stage of its evolution by addressing three contextual conundrums. Firstly, it peruses the motivational construct at every stage of development. This provides a critical insight on why corporate social responsibility was fashioned as such by analysing them contextually. Secondly, this review examines stakeholder inclusiveness at each epoch of development. This again critically exposes the category of beneficiaries included in each stage of progress categorising the evolution of their beneficiaries. Lastly, this work examines the extent of instutionalisation of corporate social responsibility illustrating the pattern in which the concept received legal and social acclamation. By addressing these three scopes, this article hopes to protrude categorically the contextual influence on corporate social responsibility so that reader(s) might understand at a deeper level the contextual reasoning and deduction on how the concept is shaped and reshaped.
\end{abstract}

Keywords: contextual review, corporate social responsibility

\section{Corporate Social Responsibility, a Labyrinth of Complexities}

Writing a review on corporate social responsibility (CSR) is popular among scholars. A search on Google with the theme "Review on CSR" reveals 6.5 million hits in merely 0.56 seconds. However, penning a CSR review is a mammoth chore. Enveloped in fads and fetishism, different occasions interpreted CSR differently. Despite pious and uproar supports, CSR never attained a fixated construction (Davis, 1976; Dahlsrud, 2008) and described as a labyrinth of confusion (Tan et al., 2018). The contradictions of definitional construct handicapped CSR's contributions in practice (Higgins, 2010). One challenge is because CSR development was never linear. From smoldering general concerns on irresponsible managers (Barnard, 1938) to bolder steps of instilling it as part of business management (Bowen, 1953; Drucker, 1954), CSR also plays 'knee jerk' response to catastrophic calamities (Davis, 1973; Frederick, 1994). For instance, following calamities like the Bhopal disaster, scholars suddenly take offense against unethical practices by introducing stringent laws (Kanu \& Uvarshi, 2018). The combination of phased evolution and revolution in CSR tasks any authors to review their development comprehensively.

A collateral problem is the depth and width CSR permeates the philosophies of business management. Moving away from simplistic philanthropy (Carroll, 1991), it has since assumed a central role in corporate strategy (Porter \& Kramer, 2002), marketing (Kotler \& Lee, 2009), talent management (Sharma \& Bhatnagar, 2009), supply chain management (Spence \& Bourlakis, 2009) and corporate reporting (Lemus, 2016). The broad spectrum of CSR literatures often misleads authors to write astray because CSR definitional construct is plagued with conflated and polarised interpretations. Indeed, many authors defined and traced the roots of CSR 
development through characterising their motivational intuitions (Petrenko et. al., 2016). Some scrutinised CSR by categorising their stakeholders (see Freeman, 2004, Mitchell et al., 2007), others studied their theoretical proliferation, from simplicity to conceptual complexities (Cochran, 2007) and a handful candidly wrote on the evolution of CSR by simply tracking their philosophical progression paths (Carroll, 1994; Agudelo \& Davidsdottir, 2019). While these attempts are honourable, they lacked sensemaking and contextualisation. Out of gas, contemporary writers vaguely classified CSR as an "international private business regulations" (Sheehy, 2014) and described that defining CSR is as "fragile cotton candy" (Reich, 2008).

To avoid those pitfalls, this article does not attempt to uncover and or discover a singular CSR definitional construct. Far from it, the current authors accept that defining CSR should remain flexible, adaptive and adequately reflects the circumstances called for (Jamali \& Mirshak, 2009). Instead, it is pervasive to fathom the contextual distinctions between the stages of CSR evolution and understand why they were a necessary design. To enhance the robustness of this review, the current authors pay premium on comparing their implicit distinctions at every stage of development from three discrete but related angles. Firstly, the authors assess the underlying motivation of CSR inquest at every stage of development. This is essential to contextualise the philosophical cognition underpinning the emergence of CSR at each stage. Secondly, it also examines the differences in the category and scope of stakeholders' (stakeholders) benefiting at every phase of this evolution. This is also necessary because the category of beneficiaries in CSR is not a fixated but an evolving and inclusive list. Finally, the current authors compare the scale of institutionalisation of CSR by scrutinising the extent of legal and social instillation of CSR as a business practice at each stage of development. Contextualising CSR development from these tripartite connections provides a richer contextual and ethnographic review.

\section{Research Method}

CSR is densely studied. There is no shortage of writings on CSR in academic journals, magazines, books and assortment of private and public reports on the same. However, one reason responsible for the complexity of CSR definitional construct is due to those overwhelming but contradicting writings. To maintain lucidity and robustness of this review, this article specifically scrutinises landmark CSR texts emphasising the narratives of leading CSR scholars. Using a systematic literature review (Okoli \& Schabram, 2010), this work targets landmark CSR literatures to produce an explicit, connected, coherent and reliable critique. The phrase 'landmark literatures' requires further exploration. Many authors who joined the bandwagon of writing on the topic have conflated and detracted the scope of the topic, some with ulterior intent and some on frolic. Therefore, to keep this review as 'pure' as possible, the works of key authors' are primarily considered. The word landmark refers to those classical writings and grounded theory which others proliferate (Bolderston, 2008). This is vital to keep the review focused and grounded where the original meaning and contexts of core literatures construed. Of course, the primary limitation of this research method is that there is scarcity of resources as many of the classical texts are not available on line. Having only access to Google Scholar and some open access journals is another hampering limitation. However, this limitation is understandable as many of these classical texts are only available in printed copy and securely kept in national libraries.

To establish an insightful review, this work is anchored on Carroll Archie's seminal work titled 'The Oxford Handbook of Corporate Social Responsibility' published in 2008. Carroll Archie is a highly regarded contemporary scholar on CSR with more than 20,700 citations to date (ResearchGate, 2018). Using this as the grounded text, this article proceeds to examine those classical texts arising from those key scholars cited in Carroll's work. The methodology is simply to key in the names of main scholars into Google Scholar and or other open access journals and to examine the classical texts of key scholars at every epoch of development to deduce the trend of thoughts and or changing patterns of arguments. Some of the classical CSR scholars that anchor this review are Howard Bowen (1953), Keith Davis (1967), William Frederick (1978), Sethi (1979), Freeman (2004), Donna Wood (1991), Carroll Archie (2008), Porter and Kramer (2001) and Yunus et al (2010). Of course, other notable supporting literatures such as Wartick and Cochran (1985), Waddock (1989) and others that analyse the core texts are also considered.

Like Carroll (2008), the review focuses primarily on developments in 1950s onwards as Carroll (2008) argued that CSR developments prior to 1950 consisted of largely unchartered and sporadic philanthropic epitomes. This review examines five stages of CSR evolution namely (1) CSR awareness in 50s (2) proliferation of CSR in 60s (3) proactive CSR and the rise of responsiveness in the 70s (4) the diversion of themes in the 80s. Finally, the (current authors) author (delete author) supplements (supplement) a fifth element of reviewing CSR in the 90's and beyond the twenty first century omitted in Carroll's work. As expressed earlier, this article enriches Carroll's work by providing contextual comparisons on the tripartite aspects of CSR cognition, stakeholder inclusion and extent of institutionalisation at every stage of its progression. 


\section{CSR, Inception of a Divine Origin}

Strange that many scholars (including Carroll's own) omitted exposing CSR's divine origin in their review. Although CSR gained momentous traction in modern management, its origin is immemorial. Writers observed that CSR entailed deep ecclesiastical foundation (Bowen, 1953). Holy testaments like the Hebrew Bible and Qu'ran contain religious enrichments on business ethics (Calkins, 2000). CSR was undefined at this stage but vaguely instilled action guiding principles for businesses (Calkins, 2000). Some literatures drew broad association between religion and general business ethics (Max Weber, 1992; McCann, 2011). Others scrutinised niche proclivities such as religion and its ethical impact on bank's financial stability and disclosure (Sobhani et al., 2011), spirituality and leadership (Fry \& Slocum, 2008; Crossman, 2011), religion, pollution and environmental preservation (Xingqiang et al., 2013).

Many businesses thrived on these religious doctrines. The legacy of Cadbury Inc. is a testament to this. Grounded on Quaker teachings and enthusiasm for social reforms, Cadbury invested heavily to develop social welfare for their workers in Bournville, a township designed to maximise workers' happiness (Bailey \& Bryson, 2007). Since then, Cadbury's brand image grew from strength to strength. Cadbury in 2005 acquired Green \& Blacks chocolate Inc. renowned for its organic and fair trade policies. In 2008, Cadbury launched the GBP 45 million cocoa partnership programme to promote social, economic and environmental sustainability of cocoa farmers in Indonesia, Ghana and India.

The halal concept in Islam is another resounding example of religion reinforced CSR. This Arabian word broadly meant any acts or consumption permitted by Islamic laws to promote social good (Ibrahim \& Othman, 2014). The halal notion is a source of competitive advantage as it increases a firm's competency, sustainability and accountability (Noorliza \& Asaari, 2017). A good example is Ayamas Food Corporation Sdn Bhd in Malaysia (Ayamas) which is the largest fresh poultry supplier in Malaysia. Study showed that the Ayamas's success is due to customers' satisfaction towards Ayamas' of halal certification for their products (Mokhtar et. al., 2014).

Many philosophers conceived that God is the superstructure of morality and ethics. Kant labelled God as an 'absolute necessity' (Petrescu, 2014). Teleology laid the universal rule of moral command in which humans must aspire to achieve and moderates the contra relationship between pursuit of wealth and social good (Petrescu, 2014). However, the association between religion and CSR is quite controversial.

A formidable concern is that religion wears two hats. On one hand, it resembled a proponent of CSR but on another, a champion of capitalism. The priority of CSR is to mitigate extreme capitalism (Lee \& Kotler, 2015), but its altruistic value diminishes when assorted with capitalism. For instance, economic prosperity, capitalist ideal and ethics intersect in Christianity. The Bible equates work and career as reverence for God and depicts the creator as a keen worker (Calkins, 2000). Max Weber's classical text 'The Protestant Ethic and the Spirit of Capitalism' published in 1930 accentuated this argument. Weber argued that the emergence of ascetic Protestantism radically revised the perceptions on savings, possession, career and wealth. It springs boarded modern capitalism and magnified the new 'religion' of wealth accumulation. This powerful momentum later led Europe to an industrial revolution and provided those European nations with a 'first mover' economic advancement (Blum \& Dudley, 2001). Islamic teachings similarly view material pursuit and spiritual enhancement as interconnected (Brammer et al., 2007). The requirement of man's active pursuit of wealth and material possession is clearly permitted in 'Takziyah' (pursuit of purification and economic growth). Economic prosperity is a central theme in Islamic teachings with a caveat that prosperity must enhance social justice.

Hence, CSR is often labelled as a self-regulating capitalism (Savevska, 2014) frequently exploited to gain competitive advantage. Its duality is paradoxical and self-defeating. Infusing CSR and the quest for business advantage is an oxymoron and sparked a familiar fear of compromising normative ethics with profit. It deepened the confrontation of the twin logics of emotional rationalism (benevolence) and intellectual rationalism (profit orientation). CSR must be stripped of a capitalist silhouette to spawn the purest reform. CSR is never a peripheral component of capitalism. Other religions take an exotic and more distant path of setting spiritual emancipation as a primal goal. In the words of the Dalai Lama "the system's moral core is neither profit nor efficiency. It is creating opportunity for individuals who need it most" (Tsinger \& Ricards, 2015). This view parallels contemporary authors who frantically preached the decays of capitalism often labelled as a big failure (Yunus, 2015), a fatal systemic flaw (Lee \& Kotler, 2015) and the root of inequality (Stiglitz, 2015).

Furthermore, religion grounded CSR is perilous because there is entrenched dichotomy in teleological interpretations. Religions embrace capitalism at varying magnitude. For example, Protestantism assumes an unfettered empowerment to accumulate wealth. The Judea-Christianity ideology prioritises the right to own property. Conversely, Islamic teachings undertakes a holistic approach that material attainment and spiritual 
emancipation is not a bifurcated but an essential coherence (Green \& Ward, 2017). Given the rift of spiritual and teleological divide, deploying a religiously tainted CSR heightens the clash of civilisation (Huntington, 1996). The 911 terrorist attack in New York is a mindful testament of this rift. Islamists view Western civilisation and capitalism as 'bloodless economics of politics' and is their primary cause for jihad (Barber, 2001). Conversely, Western views Islamiah as a 'bloody pursuit of identity politics' (Barber, 2001).

The foregoing paragraphs deliberated the religion values underpinning CSR. Many religions preach the essentials of business ethics. Philosophers classified God as an 'absolute necessity' in ethics. Some companies thrived from deploying this underlying spiritual euphoria. However, there are concerns over the paradoxical position of religion as an incredulous champion for CSR with a capitalist tint. This is a robust objection and greatly weakens its altruistic values. Religion based CSR gives way to the development of formalised and systematic secular version. The following sections review the emergence of secular CSR.

\section{The Rise of Secular CSR}

There are two demarcating features between secular and religion grounded CSR. Firstly, there is a tectonic shift from divine empowerment to the central role of corporations in secular CSR. God is no longer an 'absolute necessity'. Conversely, the rise of corporations and their expanding influence on society led scholars demanded that they behave responsibly (Bowen, 1953; Carroll, 2008). Instead of centralising on God's divine calling, corporations now shouldered the role as public trustee ensuring good deeds to the society (Frederick, 2006). With God taking a retreating position, progressing secular movements marked the rise of ethics based on social contract (Carroll, 1996).

Secondly, unlike religion-based CSR that might regress social progress, secular CSR developed exponentially through combined phases of evolutions and revolutions. Evolutionary CSR depicted a linear development through rational planning and gradual inclusion of CSR within the business framework (Cochran, 2007). From the fuzzy label of social responsibility, CSR protruded into global agenda. Revolutionary because CSR took radical forms. From a peripheral capitalist concern, CSR at its pinnacle assumed a radical business model of social enterprise devoted entirely to serve marginalised social groups (Seelos \& Mair, 2005). Secular CSR rapidly progressed and delivers exponential impact at every stage of development. The following sections of this work exemplifies the development of secular CSR and the contextual distinctions they entail.

\subsection{CSR and Growing Awareness in 1950s}

The 1950s reflects a phase of increasing recognition on the general responsibility of businesspersons to indulge in social welfare. Carroll (2008) explained that this phase is philosophically fundamental but practically dormant because it is 'all talk' with little actions, an era of cognitive shift. In Carroll's words, "to allow corporations to get comfortable with the term CSR". Writers engaged in intellectual deliberations to discover unison of concepts and directions. There are no real impactful changes where businesspersons engaged in ad hoc and directionless philanthropic movements. Carroll paralleled those philanthropic movements in the early 1900s to that in the 50s. The current authors share a different view. Carroll's treatment is simplistic and dispensed the essential underlying contexts outlining the transformation. The philanthropic movements pre and post 1950s is philosophically dissimilar. The decades before 1950s saw a conglomerate of philanthropic ideals executed under the banner of religion and spiritual devotion. The Cadbury legacy is an example of such momentum. Corporations perform charity not because they realised the damage they cause to the society, but because of the sanctity in doing so.

Corporate philanthropy perpetuated in the 50s but in a different cortex. It was not entirely an outcome of divine reverence but a cogent anxiety on the real damage that businesses inflicted the society. Howard Bowen, regarded as the 'father of modern CSR' (Carroll, 2008), in his classical work 'Social Responsibilities of Business (SRB)' published in 1953, expressed this fear. A macroeconomist eager for social reforms, Bowen was frustrated with judicial decisions like Dodge $\mathrm{v}$ Ford (Note), which reaffirmed that corporations owed no obligations to stakeholders (See also Friedman, 1975). Bowen argued that social responsibility (SR) is timely to contain raging capitalism. His social economics proposal envisioned an economy incorporating wider social inquiry encompassing relevant stakeholders such as the government, trade unions and churches to attain a better check and balance against growing corporate supremacy (Acquier et al., 2011).

Carroll (2008) vaguely mentions that SRB was written out of Bowen's fear for the rise of big corporations and their escalating impacts on the society, but more precisely, Bowen's fear pertained to the oppression and exploitation of workers. Bowen lamented against low wages, poor working conditions and campaigned against Taylor's scientific management (Acquier et al., 2011). Bowen's fears were deduced from the aftermaths of the Great Depression and historically bloody labour contexts in USA (Marens, 2008). Bowen ascribed SR as being 
"at least a partial alternative to socialism" (Bowen, 1953). He paid premium on calling corporations to diffuse their power and share their prosperity with stakeholders (Richard, 2008). This energised the widespread philanthropic momentums in 1950s focused on eradicating deteriorating labour conditions.

To the question on what motivated CSR in the 1950s, it may be tempting to conclude that Bowen is a social purist independent of religious ideals. However, this may be a misleading conclusion. In Chapter Five of SRB, Bowen controversially defended Christianity and their ideals on prosperity. Bowen defended that Protestantism does not lack the necessary ingredient to support responsible business. At the concluding chapters, Bowen remarked that profit is permissible as long as it is not abused (Acquier et al., 2008). He asserted that, "profit system is defensible if the amount of profits and their use are determined with the needs of society in view". Although a social economist, it is obvious that Bowen was gripped by Protestantism. This rendered Bowen's motivation for social reforms quasi and inchoate, bearing the residues of religious stint, a notion fervently rejected earlier in this work.

It is clear however, Bowen intended the oppressed labourers as the prime beneficiaries in this phase. Bowen pressed for autonomy of labour unions and higher wages with consideration of justice paramount (Bowen, 1953). However, other tenets such as sustainable environment are not mentioned in this classical text.

The next aspect is to examine the extent in which SR is institutionalised in this era. Ironically, while Bowen stressed the importance of SR, he reckoned that this was unachievable (Acquier et al., 2008) and made little attempt to institutionalise the theme. Two pertinent arguments supported this. Firstly, Bowen interestingly defined SR as "the obligations of businessmen to pursue those policies, to make those decisions, or to follow those lines of action which are desirable in terms of the objectives and values of our society". The word corporate does not appear in his context and he interpreted the word businessmen as the individual directors and executives of large corporations instead of the corporations themselves (Acquier et al., 2008). There is a distinction between individual SR and CSR. Roland Benabou and Jean Tirole (2010) stated that SR resembled a personal ethical execution, which is usually unstructured, ad hoc and unsystematic. CSR conversely is a corporately structured and collectively designed exercise. Bowen did not envisage an institutionalised and structured CSR commitment on corporations, but conversely appealed to the altruistic benevolence of the individual executives heading those corporations. Thus, Bowen's SR ideals lacked institutionalisation at enterprise level.

Secondly, Bowen's model also lacked legal institutionalisation of SR. Bowen maintained that SR should remain voluntary and unregulated with government usurping a subliminal role. Conversely, other scholars in his time like Selekman (1958) and Kaysen (1957) advocated that corporations will remain as irresponsible oligarchs and will never voluntarily relinquish power in the absence of legal directives. Unlike Bowen, both authors support the institutionalisation of rules and regulations to enforce corporations' commitment on SR.

The significance of CSR development in the 1950s is undermined in Carroll's seminal work. It is not an era where firms are oriented to 'feel comfy' about CSR. Far from purely a cognitive shift, it represented an intense underlying struggle of philosophers wrestling to depart from the grips of Protestantism. It is an era of quasi and inchoate attempt to escape from religious orthodoxy where corporations become sober but remain directionless on how CSR is institutionalised within the business acumen.

\subsection{Proliferation of CSR in the $1960 \mathrm{~s}$}

Carroll (2008) opined that CSR developments in the 1960s proliferated with sharper SR delineations. However, he maintained that this phase just like the 1950 s is largely philosophical debates. The current authors extrapolate this by analysing Keith Davis's writings particularly his classical work 'What Does the Businessmen Owe to the Society' published in 1967. Davis's works exceled in the 60s and is labeled as the 'runner up' to Bowen (Carroll, 2008).

The motivation of Davis's works was purely grounded on social demands. Davis unlike Bowen, degraded the role of religion in SR. Although Davis admitted that SR is founded on religion, he argued that religion grounded SR is delimited to personal philanthropy and prevented beholding a broader institutional context of the entire SR system, a point addressed earlier in this work. Davis argued that the religion-founded formula divorced personal and institutional SR initiatives. For example, Davis argued that a corporate executive may lead a righteous personal life but that did not prevent his corporation from polluting the rivers (Davis, 1967). Moving away from the centrality of religion, Davis argued that corporations are enveloped and decisively shaped by a pluralist society (Davis, 1967). To thrive in this public joint venture, corporations must fulfil those autonomous pluralistic demands. Like Bowen, Davis envisioned power sharing between various citizens in the society leading to a united ideal. In this sense, Davis's theorem marked an improvement from Bowen's because the struggle to depart 
from religion stranglehold is seemingly complete. The motivation of SR in the 1960s is incisively corporate focused and socially driven. Moving away from religious centrality, corporations now shouldered the responsibility to fulfil social demands.

While Bowen specifically championed the labours in the 50s, Davis's category of intended beneficiary is not delineated but vaguely points to fulfilling the broad demands of society. However, Davis somewhat provided a guideline on how much responsibility is expected from corporations. He argued that the more powerful a corporation the more responsibility it owed the society. How this duty is channeled and to which beneficiary is not indicated in Davis's writings.

Addressing the last issue on institutionalisation, Davis like Bowen refuted the interference of governments and rejected regulations on SR. He argued that the central reason implementing SR is to prevent regulatory intrusion. Despite the lack of legal institutionalisation of SR, Davis conversely argued that it is socially mandatory for corporations to fulfil social demands. Corporations must take responsibility for their powers failing which they will lose it (Davis \& Blomstrom, 1968). This is the 'iron law of responsibility'. Although Davis did not favour a regulatory regime, Davis surpassed Bowen's SR voluntarism model by instilling a social institutionalisation of SR. The iron law dictates a powerful social and or political sanction against defiant corporations, a more compelling factor for SR compared to Bowen's charitable mode.

\subsection{Proactive CSR and the Rise of Responsiveness in the 70s}

This is a prominent era as it marked the emergence of responsive CSR in the late 70s. Unlike other ideals that were introduced flamboyantly, responsive CSR was ushered into this era discreetly. Using the words of William Frederick (1978), a new trend that 'crept' into the realm of ongoing deliberations. Many writings explored responsive CSR cursorily including Carroll's own, dedicating only two paragraphs of his 27-page review in 2008 . Conversely, the current authors spend considerable energy on this subject as it lays a fundamental turning point in CSR development. Like previous discussions, the author deliberates according to the three central tenets of reviewing the motivations, intended beneficiaries as well as the extent of institutionalisation of CSR endeavours. The review here is grounded on the classical works of William Frederick (1978) and Sethi (1978).

Carroll argued that the 70s is a vibrant era as writers frantically attempted to delineate and design a more robust approach to instill SR in corporations. While the primary motivation in the 60s is to fulfil broad pluralistic social demands, the stimulus in the 70s is focused on the firm's proactive managerial dexterity to manage the rights and interests of the corporation and their stakeholders (Harold Johnson, 1971). Similarly, the Committee of Economic Development (CED) in 1971 opined that the future of SR depends upon the quality of managerial responses towards those public demands. The centrality of SR is how best the corporations can proactively manage such demands. Carroll (1977) argued that this managerial approach placed greater emphasis on a firm's managerial ability to proactively plan, strategise and organize CSR. Preston and Post (1975) also therorised that SR must be linked and practically transcribed into the internal managerial practices of a business firm.

Studies by Holmes (1978), Eilbert and Parket (1973) presented a host of popular SR activities corporations engaged in. Among others, this included ethics in advertising, minority protection, product defects, pollution control and support for education. This led Carroll in 1979 to introduce the term Corporate Social Performance (CSP) which required managers to undertake a three-step approach when executing effective SR activities. The three steps are (1) propose a proper definition of CSR according to the condition of the firm (2) understand the factors for which the CSR arise and (3) to devise strategies responding to the arisen circumstances.

Despite assiduous attempts to furnish a definitive description in the 70s (Heald, 1970), CSR remained a labyrinth of confusion (Higgins, 2010; Tan et al., 2018). Authors like Holmes and Carroll evaded prescribing any working definitions for CSR. Similarly, Carroll supported an open textured interpretation of CSR stating that its meaning varies according to the social expectations of the corporations at that given time (Carroll, 1979).

William Frederick in his classical piece 'From $\operatorname{CSR}^{1}$ to $\operatorname{CSR}^{2}$ ' published in 1978, expressed frustration over the infinite acrimonious debates that gripped philosophers in the 70s. Frederick implied that the definitional entrapment is due to the mistaken motivation that corporations can proactively plan, strategise and execute CSR for the betterment of the society. A proactive managerial motivation, which Frederick terms as $\mathrm{CSR}^{1}$, is honourable but impossible to execute as corporations often find themselves confronted by a penumbra of social problems that they cannot adequately address. Proactively motivated and managerial focused CSR generates imponderable possibilities spanning from marketing, philanthropy, human rights to environmental protections and other recycled moralistic slogans (Frederick, 1978; Dahlsrud, 2008). It is out of this confusion that CSR ${ }^{2}$ (responsive CSR) emerged. 
$\mathrm{CSR}^{2}$ reversed the motivation of proactive CSR. Instead of championing the managerial ability to proactively manage social expectations, Frederick argued a firm should adapt and respond to social necessities (see also Carroll, 1979). CSR managers are benchmarked not on how well they could plan ahead but how best the managers could adapt to changing social demands (Fieseler et al., 2010) and balance polarised stakeholders' interests (Maurer, 2009). Frederick argued that the shift to corporate social responsiveness implicated both philosophical and technical overtone. In a proactive CSR mode, managers are philosophically and cognitively conditioned to perceive social problems and CSR as an unrelated phenomenon and a peripheral corporate concern (Frederick, 1978). The primal motivation of proactive CSR is to cushion a firm from external hostilities instead of honestly addressing social problems (Sheehy, 2015).

Conversely, $\mathrm{CSR}^{2}$ precipitated a change in managers' cognition to a more open and receptive posture (Frederick, 1978). It presupposed a systemic process and fundamental orientation to emerging social demands. Instead of putting centrality on corporate engineered CSR, the focus shifts to understanding and responding to emerging social demands. Unlike the proactive mode that views CSR as a peripheral corporate concern, Sethi (1979) argued that responsive CSR is indispensable to preserve and maintain the legitimacy of business. A responsive posture also motivated managers to anticipate future changes and take preemptive measures to mitigate them before they transpire. Frederick's work did not provide a detail account on the technical component of responsive CSR but Sethi (1979) furnished considerable insights on this. Sethi (1979) states that there are four (4) stages in responsive CSR.

Firstly, in the pre-problem stage, firms encountered smoldering conflicts and confrontations when they execute their daily business routines. Manufacturing shortfalls and cutting corners will gradually accumulate social pressures against the firms. Depending on the pace of the snowballing pressure, firms will experience a backlash when the pressure climaxes. This effectively shifts the firm to the second stage of problem identification. Sethi asserted that various stakeholders will begin to raise their claims against the misconduct. Here, the firm will precisely delineate the extent of problem and the scope of claimants. At the third stage, the firm will begin a series of actions to pacify and compensate the stakeholders for their losses either in compensatory or punitive damages. At the final stage, the aftermath, the firm will design preemptive measures like product or process redesign to minimise the risks of reoccurrence.

In this sense, the managers' volition included both a present and futuristic responsive caliber (Sethi, 1979). The motivational contrast between proactive and responsive CSR is summarised as such. In a proactive mode, managers assume total control on designing, planning and executing CSR often regarded as a peripheral corporate concern. Conversely, responsive manager views CSR as a necessity to defend the legitimacy of corporate existence. While managers in proactive CSR are motivated to execute shortsighted CSR programmes delimited by a cost and benefit calculus (Frederick, 1978), proactive CSR anticipates and design preemptive measure to mitigate and prevent future crisis.

In terms of the extent of intended beneficiaries, proactive CSR seem to serve an indefinite class of stakeholders i.e., to balance a multiplicity of interests (Harold Johnson, 1971), to serve a wider range of human values (CED, 1971), support social order (Walton, 1982) and a fiduciary duty towards the citizens at large (Lee \& James, 1973). These infinite categories were the main concern Frederick raised in his seminal work. Frederick (1978) argued that responsive CSR narrowed the scope of beneficiaries allowing firms to focus their resources in fulfilling their specific needs. For example, Sethi's second stage of his framework provides a useful system to identify its beneficiaries. Sethi asserted that the beneficiaries are those that exert their legitimate claims against a firm. Once this category or class of beneficiaries is identified, firms should take steps to remedy their losses. Instead of striving to address the needs of an elusive class of stakeholders, Sethi's framework provides illuminating example on how these categories of beneficiaries can be typologically identified.

The last question pertains to the extent CSR was institutionalised in this era. Frederick (1998) argued that CSR ${ }^{2}$ has a broader dimension. This Frederick termed as the 'macro institutional dimension' where he viewed responsive CSR as a broader scale of institutional arrangements centred on solving issues that plague the country. Frederick advocated for a government-corporation partnership to tackle economic woes at industry and national levels. While Bowen and Davis envisaged a similar form of public private joint venture, their works did not amplify how this can be executed. Conversely, Lee and James (1975) argued that both corporations and nation states could benefit from drafting appropriate public policies that provided an aggregate guideline for firms. In their seminal work titled 'Private Management and Public Policy' published in 1975, they expressed that the public policies should reflect social demands which in turn guides the firms towards fulfilling those demands. This marks a marginal improvement in the attempt to at least formalise public policies to guide corporate behaviours. 
While $\mathrm{CSR}^{2}$ instinctively attempted to institutionalise social demands into public policies, proponents of proactive CSR perceived these as voluntary and discretionary. Carroll (1979) in his articulation of the 'pyramid model of CSR', labels ethics as voluntary donation and charitable ideals. Carroll (1991) argued that the corporate philanthropic ideal is grounded on corporate volition. It is something that is highly prized but less important than other needs of firms fulfilling the economic, legal and ethical duties. Carroll labels philanthropic responsibilities as voluntary and an 'icing on the cake'. The notion of voluntarism demarcates an insignificant interest to institutionalise CSR. Unlike Frederick, proactive CSR assumes a voluntary role based solely on the altruism of corporations to self-actualise their corporate citizenship (Carroll, 1991).

\subsection{Diversion of Themes in the $80 \mathrm{~s}$}

Instead of perpetuating the quest for a definitional construct, writers in the $80 \mathrm{~d}$ took diverse thematic approaches towards CSR (Carroll, 2008). This era raised seething concerns that writings on CSR fell short of a chronicle scientific revolution inspired by Thomas Kuhn in 1970. Despite decades of passionate debates and writings, CSR failed to accomplish a dominant, unifying and successful transition of paradigm (Thomas, 1970; Thomas, 1982; Carroll, 2008). Instead of amalgamating perspectives, writings bifurcated CSR into loosely related themes with concocted objectives. However, this resentment is exaggerated. Although there is no consensus on a definitional construct, there is consistent retreat of religion clutches at each stages of CSR development. There is also patterned development of gradual social and legal institutionalisation of CSR in the past decades. Lastly, the class of CSR beneficiaries has progressively become more illuminating through the epoch of developments.

Carroll (2008) correctly remarked that this era witnesses the genesis of two important themes, namely the stakeholder theory (Freeman, 1984) and notion of business ethics that are central to the current deliberation. Carroll (2008) fittingly described this era as a response towards colossal corporate scandals and inequity such as the Bhopal disaster that killed thousands and the infamous infant milk formula controversies in the 80 and 90s. What Carroll didn't mention was that the two themes were developed out of grieve and a surging need to contain the paradox of supercapitalism, an era demarcated by intensive privatisation and deregulation (Robert, 2008). Carroll was also probably misguided to term these emerging theories as 'alternative themes'. Far from being an alternative thematic prop, these two emerging theories forward pivotal insinuations.

Firstly, Freeman's stakeholder model reverses the polarity of CSR motivation. Like Keith, Freeman's stakeholder thesis in 1984 advocated that corporations are moral persons and must fulfil the society's pluralist demands. However, Freeman's theory digs deeper and emphasised that CSR should not merely play a fringe instrumental value. Writers often accused CSR as a fee corporation pay to reconcile their sins and wrong doings with giveaways to pacify the unrest caused by their iniquities (Goel \& Ramanathan, 2014). Instead, Freeman (1984) argued that CSR should be intrinsically instilled within the core of corporate cognition to satisfy altruistic human values and purpose (Parmar et al., 2010). Freeman (1984) and his subsequent works (see Patricia Werhane \& Freeman, 1999) fervently rejected the separation thesis and the amoral assumption that a corporation is disentangled from moral judgements. Freeman (1984) argued that corporations form part of common morality and beholding the rights and the interests of the stakeholders paved the fundamental normative moral basis of corporations (see also Donaldson \& Preston, 1995). This reversed the polarity of motivational construct of CSR in the 80s. While the predecessors perceive the importance of firms to maximise shareholders' profit and collaterally generating fringe benefits to society, Freeman's theory reverses the polarity and positions stakeholders' rights as antecedent to profits. Freeman clearly remarks, "the very purpose of a firm is to serve as a vehicle coordinating stakeholder interests...the corporation serves at the pleasure of its stakeholders..." Like Sethi who amplified the role of stakeholders (Freeman et al., 2010), this unique but commercially antithetical disposition signaled a vehement motivation to prioritise stakeholders' value and degraded capitalism. This subsequently gave rise to the notion of business ethics. The claims of business ethics and CSR are not purely a semantical distinction but contained substantial significance. Like Freeman, proponents of business ethics did not accentuate how much a corporation donates but how it makes profits in the first place (Goel \& Ramanathan, 2014).

Of course, there were doubts on the usefulness of this theory in an era of supercapitalism shrouded by powerful investors and persistent deregulations. The thought provoking book titled 'Supercapitalism, the transformation of business, democracy and everyday life' written by Robert Reich in 2007, offered a practical critique on the stakeholder model. In a supercapitalism demarcated by intensive deregulation, rise of consumerism and heightened plurality of demands, corporations often find themselves entrapped in crossfires between different proponents of stakeholders. Unable to pacify either of these groups, corporations regularly caved in to more persuasive camps. Robert Reich cited the examples of Wal-Mart support of the gay lesbian controversy and Proctor and Gamble's untimely sustenance for the passing of the Cincinnati's ordinance prohibiting against 
discrimination of homosexuals received tremendous public uproar and religious resentment. All these portrayed the oxymoron of the stakeholder theory where paying premium to stakeholders' demands risks corporations being entangled between supporters and denouncers of their CSR initiatives, setting a stage for public embarrassment (Robert, 2007).

However, Freeman argued that it is the oxymoronic feature in stakeholder theory that contributed to the contextualising of CSR. Firms no longer viewed themselves as an amoral being but gradually understand the real impact the society has upon its business values. Freeman sparked a motivational momentum to degrade capitalism and centralises the claims of the stakeholders. This dispositioning of capitalism was not envisioned in preceding waves of CSR development. Instead of seeing corporations as a separation from common morality, Freeman perceives corporations as a subsidiary of the stakeholders and they ought to play a central role to serve the higher purpose of humanity (Parmar et al., 2010).

Secondly, Freeman's thesis provided an improved analysis on the categories of stakeholders. While Davis blankly required firms to satisfy pluralist social demands, his framework did not provide a satisfactory method on delineating the class of stakeholders that a firm ought to satisfy. Conversely, Freeman's theory offered a typological approach on identifying those stakeholders. Freeman (1984) defines the term stakeholder as "any group or individual who can affect or is affected by the achievement of the firm's objectives". Though Freeman did not explicitly develop a useful matrix or stakeholder mapping, his insights on differentiating the primary and secondary stakeholders (Freeman, 1984; Parmar et al., 2010) paved the groundwork for further intellectual explorations. Eden and Ackerman's power and interest grid model developed in 1998, provided a precise classification of stakeholders according to their level of interest and influential power on the firms. Their main thesis is that a firm should always manage the expectations of stakeholders that has the highest level in both grids. Corporations can leverage on stakeholders to engender strategic intervention and even supportive alliances. In this sense, Freeman's model presented a remarkable improvement from Davis's unqualified virtuous call to satisfy pluralist social demands. Freeman's stakeholder analysis or more preferably termed as a stakeholder synthesis effectively refined the spectrum of stakeholders.

In addressing the issue of institutionalisation of CSR, Freeman's works offered an enhanced version of Davis dubious label of iron law responsibility. Instead of forcefully requiring firms to channel their values on pluralistic social demands, Parmar et al. (2010) rejected the indignities and inadequacies of various versions of capitalism including government capitalism. He argued that the fatal flaw of previous assumptions is the separation thesis that corporations remain amoral and disintegrated from ethics. Freeman opined that this naïve assumption is detrimental and consistently perceived corporations and ethics as antithesis. Freeman introduced a new term of stakeholder capitalism and like Davis, opined that the centrality of power shifted to stakeholders instead of being industrially ingrained. By infusing the interest of stakeholders as the core of business function, the perfunctory antithesis between capitalism and ethics disappears. Freeman's notion of stakeholder capitalism is a novel label and fittingly described the rise of unconventional consumerism, super globalisation leading to a very unusual disruption (Richard, 2015). How and when this shift of thoughts could materialise however, remained to be a 'question on the horizon' (Parmar et al., 2010).

\subsection{CSR in the 90s, Twenty-First Century and Beyond}

Carroll (2008) remarked that CSR developments in the 90's are largely compatible and aligned with previous momentums. Carroll stated, “... the CSR concept served as the basepoint, building block, or point-of-departure for other complementary concepts and themes, many of which embraced CSR thinking and were quite compatible with CSR". This is a sweeping statement and the word 'compatible' is a misnomer because CSR has never been 'compatible' but a dichotomous philosophy with bifurcated underlying motivation, evolving spectrum of beneficiaries and varying degrees of institutionalisation. The $90 \mathrm{~s}$ witnessed the emergence of themes such as corporate social performance (CSP), corporate citizenship (CZ) and corporate sustainability (CS) all of which further obscure CSR. Freeman correctly comments that CSR remains a 'question on the horizon' because these emerging themes further polarised the already juxtaposed CSR literatures. While Carroll's work cursorily dispensed these themes with a simplistic overview and candidly commented that these works are clustered within exclusive literatures beyond the boundaries of his work (Carroll, 2008), the present author critically reviews these concepts and their connections and or disjunctions with previous CSR developments.

CSP is an offspring of $\mathrm{CSR}^{2}$ grounded on corporations' responsiveness towards stakeholders' demands. Drawing from the previous works of Sethi, Frederick and Freeman, the primary motivation of CSP is to integrate CSR and social responsiveness into business framework and develop corporate policies addressing social issues (Wartick \& Cochran, 1985). Wood (1991) terms this as social issues management. There are three (3) central stages in the 
CSP model. Firstly, corporations must be precisely aware of their social responsibility to fulfil their economic, social, philanthropic and discretionary duties. Secondly, managers must respond to these changing social demands and thirdly, corporations must develop socioeconomic policies to mitigate 'surprises'. Like Frederick, the primal motivation of CSP is responsive rather than a proactive phenomenon. Resembling Freeman, CSP centralises the values of stakeholders, rejects the separation thesis and fervently advocates the integration of social issues into business framework. Like Sethi, Wartick and Cochran (1985) emphasise the need of a processual and integrated approach towards CSR.

It may appear that the primary motivation of CSP parallels that of Freeman, Sethi and Frederick in centralising stakeholders' interests and delimits capitalism. However, later augmentations of CSP particularly Donna Wood's writings opaque this point. Wood (1991) flamboyantly argued that Wartick and Cochran's works failed to measure the outcome of CSP but she did not provide a useful framework on how CSP is measured. This point is taken up by other writers who were keen to correlate and measure CSP. For instance, the works of Samuel and Graves (1997) and Griffin and Mahon (1997) examined the correlations between CSP and firm's financial performance. Others examined the impact of CSP on strategic human resource management (see Turban \& Greening, 1997; Greening \& Turban, 2000) while Hull and Rothenberg (2008) studied the impact of CSP on industry innovation and differentiation. These studies seem seductive but discreetly revive a familiar capitalist trajectory. Instead of centralising stakeholders' interests, these studies accentuated the economic advantage firms could derive from CSP, a point distant from what Freeman envisioned. It was argued in various parts of this work that CSR must be independent of a capitalist overtone. Although earlier CSP developments enclose an altruistic stakeholder motivation, subsequent progress elucidated an intrusion of capitalist nuance.

CSP encompassed a wider class of stakeholders. Unlike Freeman who typologically delineated their stakeholders, Wartick and Cochran (1985) argue that CSP embodies both micro and macro dimensions. They argue that firms have responsibility towards immediate stakeholders as well as to the bulk of society. This resurrected Frederick's earlier concerns on the imponderable and borderless societal distress that firms will find impossible to satisfy adequately. In this sense, CSP set an unrealistic target that is laborious to accomplish. However, in terms of institutionalisation, CSP paralleled Sethi's and Frederick's idea of government corporation joint venture by drafting the social concerns as public policy to guide corporate actions.

$\mathrm{CZ}$ is another thematic pillar in the 90s and Carroll lamented that it obscures CSR. Carroll is correct because unlike CSR that wailed the iniquities of corporations, CZ saw the sacrosanct of corporations to protect the fundamental civil, political and economic liberties of the society. Many corporations like Exxon Mobil, Nike and Ford incorporated the notion of citizenship in their corporate vision. The founding thesis of $\mathrm{CZ}$ is corporations should subrogate the role of governments that are gradually losing their sovereignty and ability to protect these civil fundamentals (Matten et al., 2003; Matten \& Crane, 2005) due to mounting supercapitalism (Robert, 2007). This motivation is controversial because corporations have regularly betrayed this trust (Adler, 2002). Moreover, $\mathrm{CZ}$ resembled more of a public relation rather than an altruistic resonance. However, unlike its predecessors, $\mathrm{CZ}$ achieved legal institutionalisation. For example, the legitimisation of the UN Global Compact (2002) stressed the ideality for corporations to forge cooperation with the civil society to instill CZ.

CS gained momentum in the 90s and further conflates CSR fundamentals. Unlike CSR, it is easier to precisely define CS where it simplistically views a development is sustainable if it does not jeopardise the capacity of future generations to fulfil their own needs (WCED, 1987). The novel motivation of CS is ecological and environmental preservation (Montiel \& Delgabo, 2014). While CSR is based on normative model, CS is largely a scientific concern (Bansal \& Chan Song, 2017). CS warned against deteriorating ecological and inculcate an urgent call to remedy deploring environmental conditions. CS was designed to fill in the gaps of CSR, which is seen to underscore naturalist symbiosis (Montiel \& Delgabo, 2014). Subsequent scholars expanded CSP to cover social variance (Gladwin \& Kennelly, 1995; Bansal, 2005).

The utmost contribution of CS is the institutionalisation of mandatory sustainability reporting regulations. Following calamities like the Exxon Valdex catastrophe, social and global pressures instigates waves of legalisation that mandate sustainability reporting (Faisal et al., 2012; Ioannou \& Serafeim, 2017). For instance, the U.S based Coalition for Environmentally Responsible Economies (CERES) launched the Global Reporting Initiative (GRI) with the objectives of establishing framework for reporting the "triple bottom line" paying emphasis to environmental performance. In Malaysia, Bursa Malaysia Berhad imposed obligatory disclosure for all publicly listed firms under Appendix 9C, Para 29 of the Bursa Malaysia Listing Requirements. It may seem that CS surpassed all previous CSR legacies as they successfully instilled global and national institutionalisation of CSR. However, the darker side of compulsory reporting is that corporations resort to lip service and exploiting sustainability reports as a marketing gimmick and greenwashing that attracts greater social backlash. 
The twenty first century also witness motivational shifts from theoretical to practical, operational and stakeholder actions (Rowley \& Berman, 2000; Carroll, 2008). Instead of procuring a theoretical construct, writers accentuated the practical aspects of CSR and examine how ethics is applied within spheres of marketing, human resource and other business tenets of the corporation. One pivotal writer in this era (omitted in Carroll's work) is Porter and Kramer's shared value model (2006). They urged corporations to integrate CSR within the value chain to gain competitive advantage. Porter and Kramer cites Nestle's investments on farmers in Moga India as an example of competitive advantage derived from strategically integrating CSR into the value chain. Other writers viewed CSR as a resource-based advantage (Mc Williams \& Siegel, 2011) and a catalyst to organisation learning and innovation (Vilanova et al., 2009). While these theorems seem seductive (Higgins, 2010), their motivations nevertheless met two fundamental objections raised earlier in this work. Firstly, this approach is smeared with capitalism and lacked ethical core. Secondly, it revitalises managerial dexterity to proactively design and plan CSR, a paradigm antithetical of a responsive slant.

\subsection{The Way Forward}

This century witnessed another powerful evolution, the rise of social entrepreneurship (SE), a point Carroll omitted. SE was spawned out of frustration over the incremental development of CSR (Googins \& Rochlin, 2000). It is not another form of CSR but an accelerator for CSR (Austin \& Reficco, 2009). In the words of Austin and Reficco (2009), "it is not another form of CSR but rather process for invigorating and advancing the development of CSR". The motivation of SE is closely aligned to Freeman's theory and rejected the separation thesis. Value creation is not a peripheral concern but underlined the DNA of a business firm (Austin \& Reficco, 2009). SE paid special attention to marginalised groups of stakeholders. Yunus (2017) for example insisted that SE must be directed to fulfill the unfulfilled needs of the marginalised society. Yunus implantation of the Garmeen Bank in Bangladesh is a resounding example of this sort. Despite the hype and pious motivation, SE has not received institutionalisation either at legal or social level and is dependent upon personal altruism and ethical emancipation (Hemingway, 2005). SE has yet seen the fullest potentiality and their contribution to mainstream CSR and social welfare remains minimal.

\section{Conclusion}

CSR has never developed linearly. On the contrary, it consisted of non-parallel changes each designed and devoted to the circumstance it endures. Therefore, penning a CSR literature through a linear approach would never adequately expose the contextual typologies of CSR development. Instead, this work comparatively reviews the typological distinctions between the epoch of CSR developments through comparing their motivation, categories of intended beneficiaries and their extent of institutionalisation. By comparing these elements, reader(s) can fathom their contextual differences and the implications emerging from these varying patterns. This work reviewed major landmark and or classical texts to derive a pure and unobscured view as much possible. By reviewing CSR in this fashion, the author hopes to instill a deeper understanding on why and how CSR has evolved in tandem to the context it encounters. However, this work provided only a simplistic treatment to SE and this phenomenon warrants an independent review. Despite the hypes and uprising trend of $\mathrm{SE}$, there is insufficient evidential data that expounds its outcomes. A literature review on SE would be a seductive exercise.

\section{References}

Acquier, A., Gond, J. P., \& Pasquero, J. (2011). Rediscovering Howard R. Bowen's legacy: The unachieved agenda and continuing relevance of social responsibilities of the businessman. Business \& Society, 50(4), 607-646. https://doi.org/10.1177/0007650311419251

Adler, P. S. (2002). Corporate scandals: It's time for reflection in business schools. Academy of Management Perspectives, 16(3), 148-149. https://doi.org/10.5465/ame.2002.8540425

Agudelo, M. A. L., Jóhannsdóttir, L., \& Davídsdóttir, B. (2019). A literature review of the history and evolution of corporate social responsibility. International Journal of Corporate Social Responsibility, 4(1), 1. https://doi.org/10.1186/s40991-018-0039-y

Austin, J., \& Reficco, E. (2008). Corporate social entrepreneurship. Int'l J. Not-for-Profit L., 11, 86.

Bailey, A. R., \& Bryson, J. R. (2007). A Quaker experiment in town planning: George Cadbury and the construction of Bournville model village. Quaker Studies, 11(1), 6 .

Bansal, P. (2005). Evolving sustainably: A longitudinal study of corporate sustainable development. Strategic Management Journal, 26(3), 197-218. https://doi.org/10.1002/smj.441 
Bansal, P., \& Song, H. C. (2017). Similar but not the same: Differentiating corporate sustainability from corporate responsibility. Academy of Management Annals, 11(1), 105-149. https://doi.org/10.5465/annals.2015.0095

Barber, B. R. (2010). Jihad vs McWorld. Random House.

Barnard, C. I. (1938). The Functions of the Executives. MA: Harvard University Press.

Bénabou, R., \& Tirole, J. (2010). Individual and corporate social responsibility. Economica, 77(305), 1-19. https://doi.org/10.1111/j.1468-0335.2009.00843.x

Blum, U., \& Dudley, L. (2001). Religion and economic growth: Was Weber right? Journal of Evolutionary Economics, 11(2), 207-230. https://doi.org/10.1007/PL00003862

Bolderston, A. (2008). Writing an effective literature review. Journal of Medical Imaging and Radiation Sciences, 39(2), 86-92. https://doi.org/10.1016/j.jmir.2008.04.009

Bowen, H. R. (1953). Social Responsibilities of the Businessman. New York: Harper \& Row.

Calkins, M. (2000). Recovering Religion's Prophetic Voice for Business Ethics. Journal of Business Ethics, 23, 339-352. https://doi.org/10.1023/A:1005989824688

Carroll, A. B. (1991). The pyramid of corporate social responsibility: Toward the moral management of $\begin{array}{lllll}\text { organizational stakeholders. } & \text { Business } & \text { Horizons, } & \text { 34(4), }\end{array}$ https://doi.org/10.1016/0007-6813(91)90005-G

Carroll, A. B. (1994). Social issues in management research: Experts' views, analysis and commentary. Business \& Society, 33, 5-29. https://doi.org/10.1177/000765039403300102

Carroll, A. B. (2008). A history of corporate social responsibility: Concepts and practices. The Oxford Handbook of Corporate Social Responsibility (pp. 19-46). https://doi.org/10.1093/oxfordhb/9780199211593.003.0002

Cochran, P. L. (2007). The evolution of corporate social responsibility. Business Horizons, 50(6), 449-454. https://doi.org/10.1016/j.bushor.2007.06.004

Crossman, J. (2011). Environmental and spiritual leadership: Tracing the synergies from an organizational perspective. Journal of Business Ethics, 103(4), 553. https://doi.org/10.1007/s10551-011-0880-3

Dahlsrud, A. (2008). How corporate social responsibility is defined: an analysis of 37 definitions. Corporate Social Responsibility and Environmental Management, 15(1), 1-13. https://doi.org/10.1002/csr.132

Davis, K. (1973). The case for and against business assumption of social responsibilities. Academy of Management Journal, 16, 312-322. https://doi.org/10.5465/255331

Davis, K. (1976). Social responsibility is inevitable. California Management Review, 19(1), 14-20. https://doi.org/10.2307/41164678

Davis, K., \& Blomstrom, R. L. (1968). Business and its environment. Academy of Management Journal, 11(2). https://doi.org/10.5465/amj.1968.4297423

Drucker, P. F. (1954). Management by objectives and self-control. Practice of management.

$\mathrm{Du}, \mathrm{X}$. (2015). Is corporate philanthropy used as environmental misconduct dressing? Evidence from Chinese family-owned firms. Journal of Business Ethics, 129(2), 341-361. https://doi.org/10.1007/s10551-014-2163-2

Eilbert, H., \& Parket, I. R. (1973). The current status of corporate social responsibility. Business Horizons, 16, 5-14. https://doi.org/10.1016/0007-6813(73)90043-8

Faisal, F., Tower, G., \& Rusmin, R. (2012). Legitimising corporate sustainability reporting throughout the world. Australasian Accounting, Business and Finance Journal, 6(2), 19-34.

Fieseler, C., Fleck, M., \& Meckel, M. (2010). Corporate social responsibility in the blogosphere. Journal of Business Ethics, 91(4), 599-614. https://doi.org/10.1007/s10551-009-0135-8

Frederick, W. C. (1978). From CSR1 to CSR2: The maturing of business-and-society thought. Business \& Society, 33(2),150-164. https://doi.org/10.1177/000765039403300202

Frederick, W. C. (1998). Moving to CSR: What to Pack for the Trip. Business \& Society, 37(1), 40-59. https://doi.org/10.1177/000765039803700103

Freeman, R. E. (2004). The stakeholder approach revisited. Zeitschrift für Wirtschafts-und Unternehmensethik, 
5(3), 228-254. https://doi.org/10.5771/1439-880X-2004-3-228

Fry, L. W., \& Slocum Jr, J. W. (2008). Maximizing the triple bottom line through spiritual leadership. Organizational Dynamics, 37(1), 86-96. https://doi.org/10.1016/j.orgdyn.2007.11.004

Garriga, E., \& Melé, D. (2004). Corporate social responsibility theories: Mapping the territory. Journal of Business Ethics, 53(1-2), 51-71. https://doi.org/10.1023/B:BUSI.0000039399.90587.34

Gladwin, T. N., Kennelly, J. J., \& Krause, T. S. (1995). Shifting paradigms for sustainable development: Implications for management theory and research. Academy of Management Review, 20(4), 874-907. https://doi.org/10.5465/amr.1995.9512280024

Goel, M., \& Ramanathan, M. P. E. (2014). Business ethics and corporate social responsibility-is there a dividing line? Procedia Economics and Finance, 11, 49-59. https://doi.org/10.1016/S2212-5671(14)00175-0

Googins, B. K., \& Rochlin, S. A. (2000). Creating the partnership society: Understanding the rhetoric and reality of cross - sectoral partnerships. Business and Society Review, 105(1), 127-144. https://doi.org/10.1111/0045-3609.00068

Green, P., \& Ward, T. (2017). The transformation of violence in Iraq. In The Criminology of War (pp. 123-141). Routledge. https://doi.org/10.4324/9781315086859-7

Greening, D. W., \& Turban, D. B. (2000). Corporate social performance as a competitive advantage in attracting a quality workforce. Business \& Society, 39(3), 254-280. https://doi.org/10.1177/000765030003900302

Griffin, J. J., \& Mahon, J. F. (1997). The corporate social performance and corporate financial performance debate: Twenty-five years of incomparable research. Business \& Society, 36(1), 5-31. https://doi.org/10.1177/000765039703600102

Heald, M. (1970). The social responsibilities of business: Company and community, 1900-1960. Case Western Reserve University Press, Cleveland, Ohio.

Hemingway, C. A. (2005). Personal values as a catalyst for corporate social entrepreneurship. Journal of Business Ethics, 60(3), 233-249. https://doi.org/10.1007/s10551-005-0132-5

Higgins, C. (2010). Is a responsive business also a responsible business. Journal of Business Systems, Governance and Ethics, 5(3), 23-32. https://doi.org/10.15209/jbsge.v5i3.186

Holmes, S. L. (1978). Adapting corporate structure for social responsiveness. California Management Review, 21(1), 47-54. https://doi.org/10.2307/41165294

Hull, C. E., \& Rothenberg, S. (2008). Firm performance: The interactions of corporate social performance with innovation and industry differentiation. Strategic Management Journal, 29(7), 781-789. https://doi.org/10.1002/smj.675

Huntington, S. P. (1996). The Clash of Civilizations and the Remaking of World Order. New York: Simon and Schuster.

Ibrahim, S., \& Othman, M. (2014). Developing and validating halal service quality instrument for Malaysian food service establishments: A conceptual paper. Procedia-Social and Behavioral Sciences, 130, 400-408. https://doi.org/10.1016/j.sbspro.2014.04.047

Ioannou, I., \& Serafeim, G. (2017). The consequences of mandatory corporate sustainability reporting. Harvard Business School research working paper (pp. 11-100).

Jamali, D., \& Mirshak, R. (2007). Corporate Social Responsibility (CSR): Theory and Practice in a Developing Country Context. Journal of Business Ethics, 72, 243-262. https://doi.org/10.1007/s10551-006-9168-4

Johnson, H. L. (1971). Business in contemporary society: Framework and issues. Wadsworth, Belmont, California.

Kanu, P., \& Urvashi, B. (2018). India after Bhopal gas tragedy and other legal systems. International Journal of Advanced Research and Development, 3(2), 1162-1169.

Karia, N., \& Asaari, M. H. A. H. (2016). Halal business and sustainability: strategies, resources and capabilities of halal third-party logistics (3PLs). Progress in Industrial Ecolog, 10(2-3), 286-300. https://doi.org/10.1504/PIE.2016.082143

Kotler, P. T., \& Lee, N. R. (2009). Up and out of poverty: The social marketing solution. Pearson Prentice Hall.

Kuhn, T. S. (1970). Reflections on my critics. Criticism and the Growth of Knowledge, 4, 231. 
https://doi.org/10.1017/CBO9781139171434.011

Kuhn, T. S. (1982). January. Commensurability, comparability, communicability. In PSA: Proceedings of the biennial meeting of the Philosophy of Science Association (Vol. 1982, No. 2, pp. 669-688). Philosophy of Science Association. https://doi.org/10.1086/psaprocbienmeetp.1982.2.192452

Lee, N. R., \& Kotler, P. (2015). Social marketing: Changing behaviors for good. Sage Publications.

Lemus, E. (2016). The Importance of CSR in Financial Reporting Standards. Global Journal of Management and Business Research.

Marens, R. (2008). Recovering the past: reviving the legacy of the early scholars of corporate social responsibility. Journal of Management History, 14(1), 55-72. https://doi.org/10.1108/17511340810845480

Matten, D., \& Crane, A. (2005). Corporate citizenship: Toward an extended theoretical conceptualization. Academy of Management Review, 30(1), 166-179. https://doi.org/10.5465/amr.2005.15281448

Matten, D., Crane, A., \& Chapple, W. (2003). Behind the mask: Revealing the true face of corporate citizenship. Journal of Business Ethics, 45(1-2), 109-120. https://doi.org/10.1023/A:1024128730308

Maurer, V. G. (2009). Corporate social responsibility and the "Divided Corporate Self": The case of Chiquita in Colombia. Journal of Business Ethics, 88(4), 595-603. https://doi.org/10.1007/s10551-009-0313-8

McCann, D. (2011). The Principle of Gratuitousness: Opportunities and Challenges for Business in «Caritas in Veritate». Journal of Business Ethics, 100(1), 55-66. https://doi.org/10.1007/s10551-011-1187-0

McWilliams, A., \& Siegel, D. S. (2011). Creating and capturing value: Strategic corporate social responsibility, resource-based theory, and sustainable competitive advantage. Journal of Management, 37(5), 1480-1495. https://doi.org/10.1177/0149206310385696

Mohtar, N. M., Amirnordin, N. A., \& Haron, H. (2014). Ayamas food corporation Sdn. Bhd: a study on the factors of consumer behaviour towards Halal product selection. Procedia-Social and Behavioral Sciences, 121, 166-185. https://doi.org/10.1016/j.sbspro.2014.01.1118

Montiel, I., \& Delgado-Ceballos, J. (2014). Defining and measuring corporate sustainability: Are we there yet? Organization \& Environment, 27(2), 113-139. https://doi.org/10.1177/1086026614526413

Okoli, C., \& Schabram, K. (2010). A guide to conducting a systematic literature review of information systems research. https://doi.org/10.2139/ssrn.1954824

Parmar, B. L., Freeman, R. E., Harrison, J. S., Wicks, A. C., Purnell, L., \& De Colle, S. (2010). Stakeholder theory: The state of the art. The Academy of Management Annals, 4(1), 403-445. https://doi.org/10.5465/19416520.2010.495581

Petrenko, O. V., Aime, F., Ridge, J., \& Hill, A. (2016). Corporate social responsibility or CEO narcissism? CSR motivations and organizational performance. Strategic Management Journal, 37(2), 262-279. https://doi.org/10.1002/smj.2348

Petrescu, A. (2014). The Idea of God in Kantian Philosophy. Procedia-Social and Behavioral Sciences, 163, 199-203. https://doi.org/10.1016/j.sbspro.2014.12.307

Porter, M. E., \& Kramer, M. R. (2006). The link between competitive advantage and corporate social responsibility. Harvard Business Review, 84(12), 78-92.

Preston, L. E., \& Post, J. E. (1975). Measuring corporate responsibility. Journal of General Management, 2(3), 45-52. https://doi.org/10.1177/030630707500200306

Reich, R. B. (2008). The case against corporate social responsibility. Goldman School of Public Policy Working Paper No. GSPP08-003. https://doi.org/10.2139/ssrn.1213129

Rowley, T., \& Berman, S. (2000). A brand new brand of corporate social performance. Business \& Society, 39(4), 397-418. https://doi.org/10.1177/000765030003900404

Savevska, M. (2014). Corporate Social Responsibility: A Promising Social Innovation or a Neoliberal Strategy in Disguise. Romanian J. Eur. Aff., 14, 63.

Seelos, C., \& Mair, J. (2005). Social entrepreneurship: Creating new business models to serve the poor. Business Horizons, 48(3), 241-246. https://doi.org/10.1016/j.bushor.2004.11.006

Selekman, S. K., \& Selekman. B. M. (1956). Power and Morality in a Business Society. New York: McGraw-Hill. 
Sethi, S. P. (1979). A conceptual framework for environmental analysis of social issues and evaluation of business response patterns. Academy of Management Review, 4(1), 63-74. https://doi.org/10.5465/amr.1979.4289184

Sharma, R., \& Bhatnagar, J. (2009). Talent management—competency development: key to global leadership. Industrial and Commercial Training, 41(3), 118-132. https://doi.org/10.1108/00197850910950907

Sheehy, B. (2015). Defining CSR: Problems and solutions. Journal of Business Ethics, 131(3), 625-648. https://doi.org/10.1007/s10551-014-2281-x

Singer, T., \& Ricard, M. (2015). Caring economics: conversations on altruism and compassion, between scientists, economists, and the Dalai Lama. Picador.

Sobhani, F. A., Zainuddin, Y., Amran, A., \& Baten, M. A. (2011). Corporate sustainability disclosure practices of selected banks: A trend analysis approach. African Journal of Business Management, 5(7), 2794-2804.

Spence, L., \& Bourlakis, M. (2009). The evolution from corporate social responsibility to supply chain responsibility: the case of Waitrose. Supply Chain Management: An International Journal, 14(4), 291-302. https://doi.org/10.1108/13598540910970126

Stiglitz, J. (2015). The great divide. Penguin UK.

Su, C., Mitchell, R. K., \& Sirgy, M. J. (2007). Enabling guanxi management in China: A hierarchical stakeholder model of effective guanxi. Journal of Business Ethics, 71(3), 301-319. https://doi.org/10.1007/s10551-006-9140-3

Teck, T. S., Ho, C. J., How, L. C., Karuppiah, N., \& Chua, W. (2018). A Theorisation on the Impact of Responsive Corporate Social Responsibility on the Moral Disposition, Change and Reputation of Business Organisations. J. Mgmt. \& Sustainability, 8, 105. https://doi.org/10.5539/jms.v8n4p105

Vilanova, M., Lozano, J. M., \& Arenas, D. (2009). Exploring the nature of the relationship between CSR and competitiveness. Journal of Business Ethics, 87(1), 57-69. https://doi.org/10.1007/s10551-008-9812-2

Waddock, S. A. (1989). Understanding social partnerships: An evolutionary model of partnership organizations. Administration \& Society, 21(1), 78-100. https://doi.org/10.1177/009539978902100105

Waddock, S. A., \& Graves, S. B. (1997). The corporate social performance-financial performance link. $\begin{array}{llll}\text { Strategic Management 303-319. } & \text { Journal, }\end{array}$ https://doi.org/10.1002/(SICI)1097-0266(199704)18:4<303::AID-SMJ869>3.0.CO;2-G

Walton, C. C. (1982). Corporate social responsibility: The debate revisited. Journal of Economics and Business, 34(2), 173-187. https://doi.org/10.1016/0148-6195(82)90032-7

Wartick, S. L., \& Cochran, P. L. (1985). The evolution of the corporate social performance model. Academy of Management Review, 10(4), 758-769. https://doi.org/10.5465/amr.1985.4279099

Weber, M. (1992). Die protestantische Ethik und der "Geist" des Kapitalismus. Verlag Wirtschaft und Finanzen.

Werhane, P. H., \& Freeman, R. E. (1999). Business ethics: the state of the art. International Journal of Management Reviews, 1(1), 1-16. https://doi.org/10.1111/1468-2370.00002

Wood, D. J. (1991). Corporate social performance revisited. Academy of Management Review, 16(4), 691-718. https://doi.org/10.5465/amr.1991.4279616

Yunus, M., Moingeon, B., \& Lehmann-Ortega, L. (2010). Building social business models: Lessons from the Grameen experience. Long Range Planning, 43(2-3), 308-325. https://doi.org/10.1016/j.lrp.2009.12.005

\section{Note}

(1919) 204 Mich. 459.

\section{Copyrights}

Copyright for this article is retained by the author, with first publication rights granted to the journal.

This is an open-access article distributed under the terms and conditions of the Creative Commons Attribution license (http://creativecommons.org/licenses/by/4.0/). 